The contribution of academic scholarship to management development

\title{
The contribution of academic scholarship to management development
}

\section{Catharine Ross, Laurence Robinson, Jan Francis-Smythe}

\section{Structured Abstract}

Purpose: This paper explores the impact of academic scholarship on the development and practice of experienced managers.

Design / Methodology: Semi-structured interviews with experienced managers, modelled on the critical incident technique. 'Intertextuality' and framework analysis technique are used to examine whether the use of academic scholarship is a sub-conscious phenomenon.

Findings: Experienced managers make little direct use of academic scholarship, using it only occasionally to provide retrospective confirmation of decisions or a technique they can apply. However, academic scholarship informs their practice in an indirect way, their understanding of the 'gist' of scholarship comprising one of many sources which they synthesise and evaluate as part of their development process.

Practical implications: Managers and management development practitioners should focus upon developing skills of synthesising the 'gist' of academic scholarship with other sources of data, rather than upon the detailed remembering, understanding and application of specific scholarship, and upon finding / providing the time and space for that 'gisting' and synthesis to take place.

Originality / Value: The paper addresses contemporary concerns about the appropriateness of the material delivered on management education programmes for management development. It is original in doing this from the perspective of experienced managers, and in using intertextual analysis to reveal not only the direct but also the indirect uses of they make of such scholarship. The finding of the importance of understanding the 'gist' rather than the detail of academic theory represents a key conceptual innovation.

Keywords: Management Development; Management Education; Academic Knowledge 
The contribution of academic scholarship to management development

Article Classification: Research

\section{Introduction}

Academic study of business and management is one, increasingly utilised, means of developing managers. The growth of this approach to development has been such that by the beginning of the $21^{\text {st }}$ century The Global Foundation for Management Education (2008 pp. 26 -27) conservatively estimated that there were at least 13.2 million students of business and management worldwide.

However, the legitimacy of business schools and MBAs, and the effectiveness of their contribution to the management development, has been questioned (see for example Wilson and Thomas, 2011). Commentators have argued that MBAs need to focus less upon developing understanding of 'facts, frameworks and theories' (Datar et al, 2011 p. 452) and more upon developing factors such as skills and values (ibid.) and skills of critical thinking, leadership and management (Muff, 2012 p. 657).

This paper adds to this debate by researching the extent to which experienced managers draw upon academic scholarship in the form of theories, models, tools and techniques when addressing managerial challenges, and the cognitive processes by which they do so. In so doing, it seeks to evaluate the contribution such scholarship makes to management development and recommend how this contribution can be enhanced.

\section{Theoretical background}


The contribution of academic scholarship to management development

Academic scholarship may take many forms. Krathwohl (2002), in his revision of Bloom's taxonomy of educational objectives, proposes four types of knowledge: factual, conceptual, procedural and metacognitive (ibid. p. 214). Factual knowledge includes terminology and specific details and elements, while conceptual knowledge includes classifications, principles, theories and models, and procedural knowledge skills and techniques. Finally, metacognitive knowledge is defined as 'Knowledge of cognition in general as well as awareness and knowledge of one's own cognition' (ibid.).

Krathwohl's revised taxonomy also indicates that individuals may follow different cognitive processes when using that knowledge. As in Bloom's original taxonomy (1956), the taxonomy of these cognitive processes follows a hierarchical structure, progressing from Remember, to Understand, Apply, Analyse, Evaluate, and finally Create (Krathwohl, 2002. p. 215). To 'Remember' involves retrieving knowledge from memory; to 'understand' being able to interpret and explain; to 'Apply' 'carrying out or using a procedure in a given situation' (ibid); and to 'Analyze' 'breaking material into its constituent parts and detecting how the parts relate to one another and to an overall structure or purpose'. At the highest levels the cognitive processes require making judgements ('Evaluate) and 'Putting elements together to form a novel, coherent whole' ('Create') (ibid.)

Benjamin and O'Reilly (2011), in a somewhat similar vein, distinguish between procedural knowledge 'which tells us how things are done' (ibid. p. 468) and declarative knowledge, 'which tells us why things work the way they do' (ibid.) However, unlike Krathwohl, they suggest that the cognitive processes followed vary according to the type of knowledge. Thus procedural knowledge is directly applied to enable individuals to undertake specific job tasks, 
The contribution of academic scholarship to management development

while declarative knowledge provides 'principles, concepts and facts' (ibid. p.469) which enable managers to address problems creatively (ibid).

An alternative categorisation is presented by Chia and Holt (2008). 'Knowledge-byrepresentation', they suggest, encompasses 'management theories, concepts, and ideas [that] are believed to represent accurately and comprehensively the actual goings-on of managerial reality (ibid. p. 472), and thus, arguably, might encompass all the forms of knowledge identified by Krathwohl and Benjamin and O'Reilly above. 'Knowledge by exemplification', by contrast, is non-scientific, describing 'ways of 'making do', rather than any formalized theories or concepts' (ibid. p. 480); crucially, it is derived from immersion in experience rather than detached observation (ibid. p. 481), and resists validation and codification (ibid. p. 480).

The relative value of such different forms of knowledge for management development has been widely debated. Discussing Krathwohl's taxonomy, for example, Brewer and Brewer (2009) suggest that metacognitive knowledge may be particularly important for managers dealing with knowledge gaps in organisations. This appears to resonate to some degree with Garvin and Cullen's (2010 p.456) claims that management education needs to focus less on facts, frameworks and theories, and more on values, attitudes and beliefs (part of the selfknowledge in the 'metacognitive' dimension), as well as the skills and techniques incorporated in the 'procedural' dimension.

Benjamin and O'Reilly (2011), however, caution against over-emphasis on procedural knowledge, arguing that it is the concepts, facts and theories which constitute declarative knowledge which enable managers to respond creatively to problems. Indeed, Veil (2011 p. 
The contribution of academic scholarship to management development

141) argues that 'by being taught the best way to complete a task, individuals are trained to act mindlessly'. Thus, Benjamin and O'Reilly conclude, 'leadership is best characterized as a combination of both procedural and declarative knowledge' (Benjamin and O'Reilly, $2011 \mathrm{p}$. 469).

Chia and Holt (2008), while decrying the elevation of 'detached explanations over practical knowledge' (ibid. p. 473) in business schools, also avoid the claim that such representations lack value for managers. Rather, they argue that they need to be supplemented (not replaced) by tacit, practical 'knowledge by exemplification'.

The importance of such tacit, unconsciously acquired knowledge is supported by literature on adult learning, which suggests that adults handle many situations through reference to a schematic record of their life experiences (Bartlett, 1967; Koffka, 1935, Minsky, 1975; Schank \& Abelson, 1997) which form 'meaning perspectives' (Mezirow, 1977) or 'trustworthy recipes' (Schutz, 1964, p. 95). Significantly, those 'recipes' are based upon the individual's memory, which, following Schacter (2001, p.195), is selective in the level of detail that it stores and retrieves. This selectivity, it is argued, enables adults to make meaningful generalisations (Hofstadter, 2001).

However, such 'recipes' can also be a barrier to development. Veil (2011) argues that 'the automatic classification of an experience with a past experience acts as a barrier to recognizing warning signals' (ibid. p. 140). Indeed, literature on adult learning suggests that it is only when an individual's 'recipes' are found wanting that learning takes place (Barr, Stimpert and Huff, 1992 p.17), and therefore new knowledge by itself will not change those 'recipes' or 'meaning-perspectives' (Mezirow, 1977, p.163), although it may serve to confirm 
The contribution of academic scholarship to management development

those already held (ibid. p.160). Consequently, Chia and Holt emphasise the importance of 'adaptability, dissimulation, alertness and vigilance' (2008 p. 480) in 'knowledge by exemplification', and argue that the role of developers is to exemplify this flexible, vigilant response to experience and indeed to representational knowledge.

However, much research into different types of academic scholarship, and their relevance, is approached from the perspective of the teacher or developer rather than the learner. Athanassiou, McNett \& Harvey (2003 p.537) for example, point out that use of Bloom's taxonomy has generally been from a 'teacher-focused, rather than learner-focused' perspective, while the revised taxonomy sets out 'what we [educators] expect or intend students to learn' (Krathwohl, 2002 p. 212). Chia and Holt (2008) also focus upon business schools and 'the nature of knowledge being produced and taught within them'.

Given the suggested importance of tacit, informally-acquired knowledge, useful insights may be gained from a learner-focused approach, which enables identification and analysis of all types and sources of knowledge which inform management development and the cognitive processes by which this occurs. This research therefore investigates the knowledge experienced managers draw upon in addressing some of their most significant challenges, in order to ascertain the contribution of academic scholarship to their development. While Benjamin and O'Reilly (2011) investigated the challenges faced by early career managers, we focus here upon experienced managers, who have had the opportunity to accumulate a wealth of tacit knowledge and to establish 'recipes' to follow, and who are therefore able to reflect on the relative contribution made by these different types of knowledge. Finally, following Krathwohl (2002) and Benjamin and O'Reilly (2011), the definition of academic 
The contribution of academic scholarship to management development

scholarship adopted encompasses both 'declarative' and 'procedural' knowledge, in the form of theories and models, and tools and techniques.

\section{Research design}

The research consisted of two sets of semi-structured interviews with senior managers. The first involved interviews with a purposive sample of 24 senior managers from five organisations. A 'senior manager' was defined as an individual who contributed to creating a strategic plan, had some corporate responsibility, dealt with complexity and ambiguity, and was required to proactively identify and implement solutions. Each of the interviewees worked within established organisations with a minimum size of 200 people and had personal responsibility for a team of at least 10 people. In addition, each had been exposed to either formal management education or programmes of management training and development. 23 of the 24 were either graduates or professionally qualified to an equivalent level; 6 had a Masters qualification in management; 5 had a management qualification at either Diploma or Certificate level; 10 had participated in comprehensive 'in house' management development training programmes, and 4 had attended short courses at a variety of established business schools.

The second data set involved telephone interviews conducted with a purposive sample of 15 similarly experienced, similarly established and similarly senior managers from a variety of organisations, who were in the midst of part-time study for an MBA at one institution. The rationale for this second data set was that, as a result of their current participation in a significant educational experience, they might be in a position to contribute insights 
The contribution of academic scholarship to management development

regarding the contribution of academic theory and tools at a time when this process might be at its most obvious and detectable.

Interview structure was based upon the critical incident technique (Flanagan, 1954). Interviewees were asked to identify two or three of their most significant, current, managerial challenges, and two or three of the most challenging managerial situations that they had experienced in the whole of their career. They were then asked to disclose the approach that they had taken to addressing each of these challenges and the source for each. Following this, interviewees were asked to identify the role that academic scholarship had played in informing the approach. Interviews were recorded and transcribed.

Initial data analysis was undertaken using thematic analysis. In the second phase of data analysis, the insights of 'intertextuality' (Bassnett, 2007) were drawn upon to ascertain whether academic scholarship, in the form of theory, models, tools or technqiues, had played a more indirect, subconscious role. This approach explores the 'explicit and implicit relations that a text or utterance has to prior, contemporary and potential future texts' (Bazerman, 2004 p.86), and enabled the research to explore empirically whether the discourse of management practitioners is made up from and / or influenced by academic scholarship.

This 'intertextual' data analysis involved identifying words and phrases of potential interest, including specific terminology, interesting metaphors and specific usages of language related to management. Within the limits of manageability the identification process was as inclusive as possible, as indicated by the fact that the resulting collation totalled 1,447 interview extracts. 
The contribution of academic scholarship to management development

Following the framework analysis technique, the identified segments of text were then examined to establish an appropriate 'index' (Richards \& Richards, 1994). Initially each extract was compared for its conformance with a range of definitions for each of eight 'index' categories: 'theory', 'model', 'concepts', 'ideas', 'approaches', 'behaviours', 'tools' and 'techniques'. Details of the definitions which were adopted for each of those categories appear in table 1 below. However, the subtleties of these definitions meant that making a meaningful distinction between some categories was problematic, so they were reduced to four 'domains': the 'theoretical', the 'conceptual', the 'tactical' and the 'practical'. Each of these encompassed two of the original 'index' categories, respectively 'theory and model'; 'ideas and concepts'; 'approaches and behaviours'; and 'tools and techniques'. This enabled the research to identify not only whether the managers' discourse was informed by academic scholarship in the form of theory/models or tools/techniques, but also to compare the extent of the contribution of these forms of scholarship.

Table 1 : Definitions adopted for indexation

\begin{tabular}{|c|c|c|}
\hline Domain & Category & Definitions \\
\hline \multirow[t]{7}{*}{ Theoretical } & \multirow[t]{6}{*}{ Theory } & A well substantiated explanation \\
\hline & & An organised system of accepted knowledge \\
\hline & & $\begin{array}{l}\text { An explanation based on observation, } \\
\text { experimentation and reasoning }\end{array}$ \\
\hline & & $\begin{array}{l}\text { A set of propositions which summarise, organise and } \\
\text { explain a variety of known facts }\end{array}$ \\
\hline & & An extremely well substantiated explanation \\
\hline & & $\begin{array}{l}\text { An abstract formulation of the constant relations } \\
\text { between entities }\end{array}$ \\
\hline & Model & A framework for thinking and acting \\
\hline \multirow[t]{2}{*}{ Conceptual } & \multirow[t]{2}{*}{ Concept } & $\begin{array}{l}\text { An abstract or symbolic tag that attempts to capture } \\
\text { the essence of reality }\end{array}$ \\
\hline & & A word, phrase or term expressing an idea \\
\hline
\end{tabular}


The contribution of academic scholarship to management development

\begin{tabular}{|c|c|c|}
\hline & \multirow{3}{*}{\begin{tabular}{|l|} 
\\
\\
Idea
\end{tabular}} & \multirow{2}{*}{$\begin{array}{l}\text { A mental picture of a group of things that have } \\
\text { common characteristics } \\
\text { An abstraction or symbol that represents similarities } \\
\text { or common characteristics }\end{array}$} \\
\hline & & \\
\hline & & The product of thinking about a problem, or issue \\
\hline & & $\begin{array}{l}\text { A specific thought that arises in the mind as a result } \\
\text { of cognition }\end{array}$ \\
\hline \multirow[t]{8}{*}{ Tactical } & \multirow[t]{4}{*}{ Approach } & Actions intended to deal with a problem, or situation \\
\hline & & To set about, go about, or to begin to deal with \\
\hline & & A way of doing things \\
\hline & & A way of dealing with, or accomplishing something \\
\hline & \multirow[t]{4}{*}{ Behaviour } & A manner of acting \\
\hline & & The actions, or reactions of an organism \\
\hline & & A response to an external, or internal stimuli \\
\hline & & The actions of people \\
\hline \multirow[t]{13}{*}{ Practical } & \multirow[t]{5}{*}{ Technique } & A way of doing something \\
\hline & & A method, or procedure \\
\hline & & A practical method applied to a task \\
\hline & & A specific method, or system of working \\
\hline & & $\begin{array}{l}\text { An approach, practical method, well defined } \\
\text { procedure, or system of working that is applied to } \\
\text { perform a task, or activity }\end{array}$ \\
\hline & \multirow[t]{8}{*}{ Tool } & An implement used in the practice of a vocation \\
\hline & & $\begin{array}{l}\text { A device that provides advantage in accomplishing a } \\
\text { task }\end{array}$ \\
\hline & & An instrument used to solve a problem \\
\hline & & A device used to perform, or facilitate a task \\
\hline & & A device that aids the accomplishment of a task \\
\hline & & $\begin{array}{l}\text { An object, device, implement, or artefact modified for } \\
\text { a particular use and used in the practice of a vocation }\end{array}$ \\
\hline & & An implement used in the practice of a vocation \\
\hline & & $\begin{array}{l}\text { A device that provides advantage in accomplishing a } \\
\text { task }\end{array}$ \\
\hline
\end{tabular}


The contribution of academic scholarship to management development

A number of measures were adopted to enhance the reliability and validity of the research. These included (i) a commitment to a 'low inference' indexing system (Robson, 2002); (ii) the explicit presentation of the rules by which indexation was carried out (Miles and Huberman, 1984); (iii) the presentation of interview extracts within their context (ibid); and (iv) the triangulation of the findings of the intertextual analysis with the analysis of the verbatim interview transcripts.

\section{Findings}

The semi-structured interviews found that experienced managers made little explicit reference to academic scholarship when responding to challenges in the workplace. As detailed in a previous paper, the managers' responses were much more likely to be based upon fellow professionals, intuition, personal experience and values (Francis-Smythe et al, 2013). Indeed, only 13 of the 39 interviewees were able to point to any instances in which academic scholarship had played any part in informing their approach to a challenging situation.

Moreover, when these interviewees were asked what role academic scholarship had played in their practice, they suggested that its most significant, direct, obvious role was in relation to the retrospective confirmation of their established managerial practices. Thus:

'I think they've been useful in confirming what a lot of my ideas are'. 
The contribution of academic scholarship to management development

'You think, ... I've always sort of thought that, but now there's like a confirmatory science behind it'.

The second way in which the managers occasionally reported using academic scholarship to inform their practice was in relation to the implementation of specific tools and techniques. Interviewees explained:

'I tend to use management books to focus upon a particular area that I am working on and specifically looking for new angles, new ways of doing things and new tools to work with...'

'Some of [the academic materials] I kind of felt like I never want to look at this again. Um.... But other ones... um... were incredibly practical.'

'[Adair's action-centred leadership] was simple and useable..... I feel if I can keep it in my head and pull, pull... use it as a resource to pull people back'.

Interviewees were then asked to explain this apparently very limited role of academic scholarship in addressing significant managerial challenges. In response to this direct question 10 of the 39 interviewees suggested that any such influence was probably covert, indirect, subconscious, or even subliminal:

"I don't know, it's always subconscious".

"It sits in the back of your mind and helps your work". 
The contribution of academic scholarship to management development

“Unconsciously I'm sure it's there”.

It is this suggestion that was examined through the 'intertextual' analysis. Following the process discussed above, this analysis indexed the discourse of the interviewees to four 'domains': the 'theoretical', the 'conceptual', the 'tactical' and the 'practical'. The result of this indexing is illustrated by Table 2 below, which shows 152 (or 10\%) of the 1,447 total indexations (Patton, 1987).

Table 2: Sample of indexation arising from intertextual analysis.

\begin{tabular}{|l|l|l|l|}
\hline Theoretical Domain & Conceptual Domain & \multicolumn{1}{|c|}{ Tactical Domain } & Practical Domain \\
\hline \multicolumn{1}{|c|}{ Theories \& Models } & \multicolumn{1}{|c|}{ Concepts \& Ideas } & \multicolumn{1}{c|}{$\begin{array}{c}\text { Approaches \& } \\
\text { Behaviours }\end{array}$} & Tools \& Techniques \\
\hline $\begin{array}{l}\text { Action centred } \\
\text { leadership }\end{array}$ & Accountable & Abdicate & Action plan \\
\hline Aggressive & Ambition & Adapt & Agenda \\
\hline Best value & Authority & Arrogant & Benchmarking \\
\hline Bureaucracy & Best practice & Autocratic & Body language \\
\hline Centre of gravity & Busking & Bullying & Budget \\
\hline Centres of excellence & Champion & Charismatic & Business plan \\
\hline Completer - finisher & Change agent & Coaching & Checklist \\
\hline Culture & Confidentiality & Compromise & Decision tree \\
\hline Ego & Contingency & Consult & Delegation \\
\hline $\begin{array}{l}\text { Emotional } \\
\text { intelligence }\end{array}$ & Core business & Cynical & Gap analysis \\
\hline Encouraging the heart & Cross - fertilise & Debate & Implementation plan \\
\hline Energy & Cross cutting & Direct & Job description \\
\hline Evolution & Devolved & Explore & KPI \\
\hline Focal point & Diverse & Facilitate & $\begin{array}{l}\text { Managing by } \\
\text { exception }\end{array}$ \\
\hline Group dynamics & Dotted line manager & Goal setting & Manpower planning \\
\hline Inertia & Dumped on & Influence & Mystery shopping \\
\hline $\begin{array}{l}\text { ISO 9001 } \\
\text { accreditation }\end{array}$ & Empowerment & Instinct & Objective \\
\hline Lean organisation & Entrepreneurial & Internalise & Prioritise \\
\hline Learning styles & Ethic & Logical & Process mapping \\
\hline Matrix organisation & Expedient & Mediation & Schedule \\
\hline Momentum & Global footprint & & \\
\hline & & Bisk management \\
\hline
\end{tabular}


The contribution of academic scholarship to management development

\begin{tabular}{|c|c|c|c|}
\hline $\begin{array}{l}\text { Myers Briggs type } \\
\text { indicator }\end{array}$ & Headhunted & Naïve & Scorecard \\
\hline NLP & Hierarchy & Navel gazing & $\begin{array}{l}\text { Service level } \\
\text { agreement }\end{array}$ \\
\hline Osmosis & Inclusive & Negotiate & Stakeholder \\
\hline Pivotal point & Integrity & Obsequious & Succession planning \\
\hline Prince two & Invest & Persuade & Target \\
\hline Situational leadership & Managing up & Pig headed & Terms of reference \\
\hline Storming & Morale & Reactive & To do lists \\
\hline Strategic planning & Pace & Refining & \\
\hline Supply chain & Pathfinder & Segment & \\
\hline Team briefing & Pride / Proud & Sensible & \\
\hline Transactional analysis & Privileged & Shock & \\
\hline \multirow[t]{18}{*}{ Waves } & Proactively & Smart arse & \\
\hline & Professional & Soul searching & \\
\hline & Quick \& dirty & Systematic & \\
\hline & Red herring & $\begin{array}{l}\text { Top down / Bottom } \\
\text { up }\end{array}$ & \\
\hline & Rites of passage & Turnkey & \\
\hline & Shadowing & $\begin{array}{l}\text { Twiddling their } \\
\text { thumbs }\end{array}$ & \\
\hline & Silo & Vociferous & \\
\hline & Sound bite & Working group & \\
\hline & Sounding board & Workshop & \\
\hline & Step up to the plate & & \\
\hline & Success & & \\
\hline & Synergies & & \\
\hline & Touch points & & \\
\hline & Touching base & & \\
\hline & Tunnel vision & & \\
\hline & Vertically integrated & & \\
\hline & Watchdog & & \\
\hline & Whinge - fests & & \\
\hline
\end{tabular}

In line with the interviewee comments noted above, the intertextual analysis revealed a number of extracts which could be indexed to the theoretical domain, thus showing remnants of formal academic theory. Moreover, detailed analysis of the interview transcripts revealed that even where interviewees failed to 'name' a theory they understood its principles. Thus, in the illustrative extracts below, it is clear that each of these two interviewees could have referred to a specific model, such as 'situational leadership' (Hersey and Blanchard), although they did not do so: 
The contribution of academic scholarship to management development

'I've always been someone who's given a lot of answers, you know, you need to do this in that way, or you need to do this in this way... And I guess I actively, ... I've tried to change my approach with this person ... um ... and, you know, just tried to be a lot more coaching in my style'.

'I have people on my team that are experienced ... and there's only one person [who is] a placement student. So OK, with her, I have to have a slightly different approach, more direct and a lot more close coaching'.

In one specific example, an interviewee from the part-time MBA cohort had been so strongly influenced by the topic of 'delegation', when raised in the context of an MBA seminar, that he had radically altered his personal approach to management and undertaken a significant restructuring of his whole department. Subsequently, the lecturer concerned was able to confirm that the discussions regarding delegation had been framed within structured input in relation to 'situational leadership' (Hersey \& Blanchard) and 'empowerment' (Kanter). Despite this, within the verbatim interview transcript, there was no mention of either of these 'theoreticians', or the relevant theory and models.

This analysis therefore suggests that managers' development is often informed by their indicative, 'gist' based understanding of academic theory, rather than by the detailed theory or models. As one interviewee explained:

“... there are many theorists out there ... I wouldn't think that I draw on anybody in particular ... what takes me forward is the understanding of the 
The contribution of academic scholarship to management development

concepts. ... Certain lecturers at college enthuse about certain writers, ... I'm very much more about looking at the wider picture".

Moreover, it was the practical implications that were of interest. As another interviewee reported:

"I'll kind of forget some of the words and some of the names because I'm trying more to remember some kind of examples or some tips that then I can practise".

The managers' key concern, therefore, was to abstract concepts and tactics from the academic theory. Given this, it is unsurprising that the intertextual analysis revealed at least as many interview extracts that were potentially capable of being indexed to the 'conceptual' and 'tactical' domains as to the 'theoretical' or 'practical'. Academic theory, it appears, informed experienced managers' development of concepts and tactics, and, faced with significant challenges, it was often to these more abstracted domains that managers referred.

Moreover, the verbatim interview transcripts revealed that this 'gist'-based understanding of academic theory became part of an ongoing internal dialogue. As interviewees explained:

'It was therefore being able to match [details of technical role omitted] experience with the managerial experience and then using the academic thing to consolidate that'

'I'm entering a phase right now where I'm big into linking certain dots and I'm, I'm building something in my head...' 
The contribution of academic scholarship to management development

This dialogue continued outside work time, and could be informed by an almost infinite number of sources:

'[The] news, or anything like that, triggers you off.'

'I can't read any paper without relating something in it back to work, even when I'm relaxing at the weekend'

Even the remnants of academic theory which did inform this internal dialogue were not limited to theory from the discipline of management alone. $16 \%$ of the extracts indexed to the 'theoretical' domain were theoretical terms from disciplines other than management or psychology, such as 'catalyst', 'centre of gravity', 'focal point', 'inertia', 'momentum', 'osmosis' and 'tangent', further demonstrating the range of sources on which managers drew.

For the most part, therefore, what managers appropriated was not specific theory but an understanding of the 'gist' of it. This, the data suggested, was then synthesised with information from other sources such as past experiences, fellow professionals, family and values, in a continual internal dialogue.

\section{The development of experienced managers}

This research has revealed that academic scholarship had only a limited, direct influence on the practice and development of experienced managers. One way in which it did inform their practice was by providing retrospective confirmation for previously established managerial practices, in line with Mezirow's (1977) proposition that new knowledge can be an important 
The contribution of academic scholarship to management development

'after-the-fact' element. However, as Veil (2011) has noted, the tendency to notice only information which confirms our existing perspectives can present a barrier to learning, and thus this use of academic scholarship may actually hinder, rather than enhance, development.

The second key way in which academic scholarship sometimes contributed directly to management practice was through managers adopting specific tools or techniques that they had been taught. Such knowledge relates to the 'procedural knowledge' presented by Krathwohl (2002) and Benjamin and O'Reilly (2011), and involved the managers in the cognitive processes of remembering, understanding and applying (Krathwohl, 2002). Interestingly, in these instances managers did not demonstrate the higher, more creative and critical, levels of Krathwohl's hierarchy of cognitive processes. This suggests that, as Benjamin and O'Reilly argue, procedural knowledge may aid managers in addressing routine problems but may by itself inhibit creativity (ibid. p.470). Again, therefore, this use of academic scholarship could present a barrier to learning, leading to 'trained mindlessness' (Veil, 2011 p.141).

However, academic scholarship, particularly in the form of theories and models, also made a more indirect contribution. In these instances the scholarship informed a continual, ongoing internal dialogue, along with other sources such as past experiences and inputs from fellow professionals (Francis-Smythe et al 2013), upon which the managers' 'meaning perspectives' (Mezirow, 1977) and 'trustworthy recipes' (Schultz, 1964) were based. Significantly, what informed this dialogue was not the detailed application of specific scholarship, as in Krathwohl's (2002) cognitive process of 'apply', but managers' further abstraction of them, based on the necessities of the managerial challenges they faced. This is in line with adult learning theory, which suggests that 'recipes' are based upon a 'schematic' rather than 
The contribution of academic scholarship to management development

detailed record (Bartlett, 1967; Koffka, 1935, Minsky, 1975; Schank \& Abelson, 1997). Thus it appears that managers do not follow the lower levels of Krathwohl's structure of cognitive processes (to 'remember', 'understand' and 'apply') when engaging with theory and models, but immediately adopt a more active, creative and critical role in selecting those aspects most relevant to their situation.

While managers may occasionally have directly applied procedural knowledge, therefore, for the most part when engaging with academic scholarship they demonstrated the higher levels of Krathwohl's structure of cognitive processes, synthesising their 'gist'-based understanding of it with knowledge from different sources in a continuous internal dialogue as they strove to address the challenges they faced. Such dialogue appears to conform to Chia and Holt's 'knowledge by exemplification', both in its grounding in real-life situations, and the vigilance, care and assessment demonstrated. Moreover, and crucially, this demonstration of the cognitive processes of 'analyse', 'evaluate' and create' (Krathwohl, 2002 p. 215) may enable managers to avoid the possible barriers to development presented by direct application, noted above.

This finding again concurs with Benjamin and O'Reilly's (2011) claim that while procedural knowledge is applied directly and without transformation, declarative knowledge can help managers to be creative. Furthermore, it suggests that, although Chia and Holt (2008) differentiate between knowledge by representation and knowledge by exemplification, and suggest that theories and models form part of the former category, such academic scholarship actually constitutes part of managers' 'knowledge by exemplification' in the same way as other experiences. Knowledge by exemplification, Chia and Holt claim, is derived from 'dwelling' in the environment, which 'takes on significance through our responsively 
The contribution of academic scholarship to management development

incorporating selective aspects of it into our everyday activities according to the demands of the situation we find ourselves in' (ibid. p. 479), and from the managers' transcripts it is clear that they are using the much of the academic scholarship they encounter in exactly this way.

\section{Summary and conclusions}

Current literature suggests that management development requires less of a focus on understanding 'facts, frameworks and theories' (Datar et al, 2011 p. 452), and more of a focus on the development of skills of critical thinking and management, and understanding of personal values. Others, in a similar vein, have argued that effective management requires managers' understanding of such representational knowledge to be supplemented by the development of tacit knowledge derived from continual, vigilant assessment of their environment (Chia and Holt, 2008). However, the literature also cautions against relying solely on the learning of procedures (Benjamin and O'Reilly, 2011), suggesting that this may hinder development.

In many respects the research presented here supports this literature, revealing that, while detailed understanding of specific procedures may be of use in some instances, managers' development is informed little either by a detailed understanding of specific theory and models or by an ability to recall these with complete accuracy. However, the findings do not suggest that academic scholarship in the form of theories and models makes no useful contribution to management development. On the contrary, they show that experienced managers abstract what they find relevant from academic scholarship of this kind and put it together with knowledge from a wide range of other sources as part of a continual, creative, internal dialogue. Crucially, therefore, what these findings provide is empirical evidence, 
The contribution of academic scholarship to management development

from the managers' perspective, of the kinds of academic scholarship they find useful for their practice and the different ways in which they use them.

These findings have important implications for the development of managers. In the first place, they indicate that academic scholarship in the form of theories and models can make a useful contribution to management development. In the second place, however, they suggest that developing certain cognitive processes- the ability to 'remember', 'understand' and 'apply' such scholarship - may not always be helpful. By contrast, they show that a key skill managers need to develop is the ability to abstract what is relevant from the almost infinite range of sources -including academic scholarship - they encounter.

In the third place, and relatedly, the findings show that, if management development is to avoid creating barriers to learning, it needs to encourage managers to adopt an active, vigilant approach to the whole range of knowledge they encounter. Rather than supplementing knowledge by representation with knowledge by exemplification, therefore, management development needs to ensure that the two forms of knowledge are synthesised, so that the gist of representational knowledge becomes part of managers' ongoing assessment of their environment.

Finally, the findings suggest that there is indeed a continuing role for business schools and management education programmes in management development. Not only can they provide declarative knowledge which can encourage management creativity (Benjamin and O'Reilly, 2011), and demonstrate how such representational knowledge may be combined with knowledge by exemplification (Chia and Holt, 2008), but they can provide a time and space 
The contribution of academic scholarship to management development

for that activity. In the words of one interviewee: 'It's thinking outside the box, about having the bloody time to think outside the box'.

\section{References}

Nicholas Athanassiou, Jeanne M. McNett and Carol Harvey (2003) "Critical Thinking in the Management Classroom: Bloom's Taxonomy as a Learning Tool" Journal of Management Education Vol. 27 pp. 533-555

Barr, P.S., Stimpert, J.L. and Huff, A.S. (1992) "Cognitive change, strategic action and organisational behaviour" Strategic Management Journal, Vol. 13, Special Issue: Summer pp.15-26.

Bartlett, Sir F. C. (1967). Remembering: A study in experimental and social psychology. Cambridge: Cambridge University Press.

Bassnett, S. (2007) "Influence and intertextuality: A reappraisal", Forum for Modern Languages Vol. 43, No. 2 pp.134-146.

Bazerman, C. (2004) Intertextuality: How texts rely on others texts. In C.Bazerman and P.Prior (eds.) What writing does and how it does it: An introduction to analying text and textual practices, Mahway, NJ: Lawrence Erlbaum

Benjamin, B. and O'Reilly, C. (2011) "Becoming a Leader: Early Career Challenges Faced by MBA Graduates", Academy of Management Learning and Education, Vol. 10 No. 4 pp. $452-472$.

Bloom, S. (1956) Taxonomy of Educational Objectives: The Classification of Educational Goals, Handbook 1: Cognitive Domain, NY: David McKay

Brewer, P. and Brewer, K. (2010) "Knowledge Management, Human Resource Management, and Higher Education: A Theoretical Model”, Journal of Education for Business, Vol. 85 No. 6 pp. $330-335$ 
The contribution of academic scholarship to management development

Chia, R. and Holt, R. (2008) "The Nature of Knowledge in Business Schools", Academy of Management Learning and Education, Vol. 7 No.4, pp. 471-486.

Datar, S., Garvin, D. and Cullen, P. (2011) "Rethinking the MBA: business education at a crossroads", Journal of Management Development, Vol. 30 No. 5 pp.451-462.

Flanagan, J.C. (1954) "The Critical Incident Technique" Psychological Bulletin Vol. 51, No.4 pp.327-358

Global Foundation for Management Education. (2008). The global management education landscape: Shaping the future of business schools.

Available at http://www.gfme.org/landscape/landscape.htm (accessed 11 September 2009)

Francis-Smythe, J., Robinson, L., Ross, C. (2013) "The role of evidence in general managers' decision-making", Journal of General Management, in press.

Hofstadter, D. (2001). "Analogy as the core of cognition" in Gentner, D. Holyoak, K. \& Kokinov, B. (Eds), The analogical mind: Perspectives from cognitive science. Cambridge, MA: MIT Press.

Koffka, K. (1935). Principles of Gestalt Psychology. London: Routledge and Kegan Paul.

Krathwohl, David R (2002) “A Revision of Bloom's Taxonomy: An Overview”, Theory Into Practice, Vol.41, No.4, pp. 212-218

Mezirow, J. (1977). Perspective transformation. Studies in Adult Education, Vol.9, No.2,: 153 $-164$.

Miles, M.B. and Huberman, A.M. (1084) Qualitative data analysis, Beverley Hills, CA: Sage Publications

Minsky, M. (1975). “A framework for representing knowledge” in Winston, P. H. (Ed), The psychology of computer vision. New York: McGraw-Hill. 
The contribution of academic scholarship to management development

Muff, K. (2012) “Are business schools doing their job?" Journal of Management Development, Vol. 31 No. 7 pp. 648-662.

Patton, M.A. (1987) How to use qualitative methods in evaluation, Newbury Park, CA: Sage Publications

Richards L. and Richards, T. (1994) "From filing cabinet to computer" in Bryman, A. and Burgess, R.G. (eds.) Analysing Qualitative Data, London: Routledge.

Robson, C. (2002) Real world research: A resource for social scientists and practitionerresearchers, $2^{\text {nd }}$ ed., Oxford: Blackwell Publishing

Schacter, D. L. (2001). How the mind forgets and remembers: The seven sins of memory. London: Souvenir Press Ltd.

Schank, R. C. \& Abelson, R. P. (1997). Scripts, plans, goals and understanding. Hillsdown, NJ: Erlbaum.

Schutz, A. (1964). "The stranger: An essay in social psychology" in Brodersen. A. (Ed), Collected Papers II: Studies in Social Theory. The Hague: Matinus Nijhoff.

Veil, S. (2011) "Mindful Learning in Crisis Management", Journal of Business Communication, Vol. 48 No. 2 pp. 116-147.

Wilson, D., Thomas, H. (2012) "The legitimacy of the business of business schools: what's the future?" Journal of Management Development, Vol. 31 No. 4, pp.368-376. 